\title{
SECURITY AND INTELLIGENCE COMMUNITY OF THE REPUBLIC OF NORTH MACEDONIA
}

\begin{abstract}
The world in the 21st century has proven to be a dangerous and unsafe place to live full of unpredictable threats and risks that vary in form and intensity of manifestation. Due to the unpredictable trajectory of the dangers, there is a need to obtain timely, accurate, and verified intelligence data on the situation in certain regions and countries. Thus the modern intelligence services whose primary role is to protect the state and its vital interests from various types of security threats and risks were developed. Hence, we will analyze the process of reforms in the security-intelligence sector as an important segment for the integration of R.N.Macedonia in the Euro-Atlantic structures. At the same time, we will perceive the place and role that the security and intelligence services have as key entities in the national security system of the Republic of North Macedonia in order to take preventive and repressive measures in the fight against modern threats, as well as their legal competencies in the field of security and intelligence.
\end{abstract}

Keywords: SECURITY, REFORMS, INTELLIGENCE COMMUNITY, JURISDICTIONS.

\section{Introduction}

The Republic of North Macedonia has faced a number of challenges and dangers when establishingthe state and its own security system since it gained independence until today. In the 90s, unfortunate events took place on which the survival of the country and the stability of the region depended, starting from the events that led to the disintegration of the former SFR Yugoslavia on whose territory several wars were fought, to constant political pressures, economic blockades, border incidents, refugee crises, genocides and conflicts that threatened the security of the state. In addition to these events, other processes and directions of development related to the security and defense system took place in parallel, which contributed to concerns among the state leadership. They refer to the new model of the security system, the way of transformation and restructuring of the security structures, and the steps that should have been taken in the process of approaching the NATO and the EU standards (Зенделовски, 2010:295-307).

In addition to the series of problems and difficulties we faced during the reforms and the building of the security system, the Kosovo crisis in 1999, 
as well as the armed conflict in 2001, the situation in the country got complicated. Series of activities and changes in the country's politics and state order followed. First, there were interventions in the Constitution, then in the legislation, and finally the adoption of documents related to the security and defense of Macedonia.

Our state has built its security system according to the needs and changes inside the state and on the basis of the modern security environment. In the performance of its security function, the security system of R.N. Macedonia consists of three interconnected segments, which are:

(1) The legal norms and laws that regulate the relations in the field of security, which are: The Constitution of RNM, the Law on Internal Affairs, the Law on Police, the Law on Defense, the Law on Intelligence Agency, the Law on Classified Information, Law on Agency for National Security, Law on Operational-Technical Agency, Law on Coordination of the Security and Intelligence Community. In addition to the legislation, R.N. Macedonia adopted several essential strategic documents, including the National Security and Defense Concept, White Paper on Defense, National Security Strategy, Defense Strategy, which created the fundamental predispositions for profiling the essential elements in the field of national security and defense (Бакрески и Милошевиќ, 2010). These documents are an indicator that Macedonia has a well-developed strategic framework for security and defense, as well as a well-established and developed system of national security. The established political and normative framework of strategic documents shows what the national security policy should look like and in which direction it will move and how the national security system will develop in the context of modern security trends (White Paper on Defense, 2012).

(2) The institutions that perform security functions and that have rights, duties, and responsibilities in achieving security which are: The President of RNM, Assembly of RNM, Government of RNM, Ministry of internal affairs, Ministry of Defense, Intelligence Agency, The Agency for National Security, the Operational Technical Agency, the Security Council, the National Cyber Security Council, the Councilforcoordination of the Security-Intelligencecommunityand others.

3) Security measures that achieve security in practice (Спасески, 2005: 272).

The security-intelligence system is part of the national security system of the R.N. Macedonia and its competencies, powers, and tasks are regulated by laws and other regulations (Бакрески,2018). In general, the security and intelligence services are responsible for collecting and analyzing data and information relevant to the security of the country and the protection of its vital interests. These services play a great role in protecting the social, political and economic order of the state and its institutions from external and internal threats, therefore, states need effective intelligence in order to make appropriate national security decisions (Фуиор, et al.2018). 


\section{Security and intelligence sector reforms}

The security and intelligence services operate in secret and have the power to use special authorization in order to collect and analyze data of national security interest. There is a risk that this information will be misused in the context of state policy and constitutionally guaranteed human rights and freedoms can beviolated, and because of that intelligence services can easily become a threat to society and become a generator of crises instead of security providers. Because of these reasons, the intelligence services are observed with suspicion and mistrust by the public, so there is a need for greater accountability and democratic (parliamentary) oversight and control of their work rather than the work of other government agencies (ibid.,4).

In the past, R.N. Macedonia has faced two major controversial events related to the abuse of security and intelligence services. The first affair (known as the "Big Ear") erupted in late 2000 when it was discovered that there was massive illegal use of telecommunications by the Ministry of internal affairs structures to wiretap politicians, businessmen, journalists and diplomats (Чомовски, 2007). The second affair, which took place in early 2015, sparked a deep political crisis in the country. The affair arose when the Macedonian public was exposed to wiretapped conversations (known as "the bombs") and the widespread illegal interception of communications by the "secret" services (European Commission Report on the Republic of Macedonia, 2016). This scandal with mass wiretapping of more than 20,000 citizens for the period from 2008 to 2015 led to increased international pressure on Macedonia's political leaders, which ultimately resulted in the signing of the Przino Agreement in 2015. Both affairs involved senior government officials who then ran security institutions and services ${ }^{1}$ (MacDowall, 2015).

These events contributed to the launch of the security and intelligence services reform, which was requested by the European Union based on the findings of the expert group of the European Commission(Recommendations of the Senior Experts' Group on systemic Rule of Law issues relating to the communications interception revealed in spring,2015). NATO also called for security sector reform as one of the conditions for the country's membership in the Alliance. The recommendations for oversight and restructuring of the intelligence services set out in the document Urgent Reform Priorities - URP, (as an official document of the European Commission containing specific guidelines for action) and the Recommendations of the group of senior experts on systemic rule of law issues related to the monitoring of communications, were not implemented in practice (Urgent reformprioritiesfor The Former Yugoslav Republicof Macedonia, 2015). The events in the Parliament of the RNM (known as

\footnotetext{
${ }^{1}$ The Przhino agreement provided formation of a technical government involving opposition representatives, media reform, separation of the political parties from the state and an establishment of a Special Public Prosecutor's Office (SPO) to work on wiretapping cases and to create the conditions for fair and democratic early parliamentary elections.
} 
"Bloody Thursday") on April 27, 2017, in which senior officials from the security institutions were involved, showed that the country did not get a functioning security system, especially not in terms of the work of the intelligence services.

The events were a trigger to launch activities related to comprehensive intelligence sectorreform with support from the EU, NATO, and strategic partners. The reforms of the security-intelligence services were implemented by the Government of the RNM, which were outlined in the Plan 3-6-9 and in the Plan $18^{2}$, in order to implement the EU reform agenda and start the negotiations for membership in the Union. These plans are in line with the oversight and intelligence services reform recommendations contained in the Urgent Reform Priorities.

According to Government Plan 18, in the area of security and intelligence services reform, the focus is on: (1) implementing the full package of measures related to the full operationalization of the OTA, through the adoption of the remaining laws and the adoption of bylaws; (2) Establishment of a Council for Civilian Supervision; (3) Complete reform of the intelligence services by adopting a Plan for reform of the security-intelligence sector. Plan 18 provides that by the end of 2018, all competent services will prepare a complete reform of the intelligence services by adopting a Plan for reform of the security-intelligence sector which should contain the new model of restructuring the security-intelligence system in R.N. Macedonia with a plan for its implementation (Plan 18, 2018).

In order to meet Euro-Atlantic standards, a package of legal solutions was adopted in a short period of time, which enabled the desired reform. The changes started with the reforms of the communications interception system, with the adoption of a new Law on Interception of Communications (2018) and the amendment of the Law on Electronic Communications (2018), which deprived the direct access of the Directorate forSecurity and Counterintelligence (UBK) to citizens' telecommunicationstraffic. Then came the laws establishing the new security institutions, such as: the Law on Operational-Technical Agency, which regulates the establishment of the Operational-Technical Agency (OTA), its competencies related to the monitoring of telephone and electronic communications; The Law on Agency for National Security, which provides for the newly established Agency for National Security(ANB) to replace the existing Directorate forSecurity and Counterintelligence, which will no longer be a state body within the Ministry of Interior; The Law on Coordination of the Security-Intelligence Community, which covers the security and intelligence services of the R.N. Macedonia provides the establishment of a special state body, the Council for Coordination of the Security-Intelligence Community. This was followed by a review of the legislation governing which regulates the work of the Intelligence Agency and the Military Service for Security and Intelligence of the

${ }^{2}$ Plan 18 was adopted at a regular session of the Government in 2018, it is divided into four key reform areas: judiciary, security and intelligence services, public administration reform and the fight against organized crime and corruption. The progress in these key areas is incorporated in the European Commission's Annual Report. 
Ministry of Defense. This fully completed the process of reform of the security and intelligence sector, and the newly established agencies and state bodies were put into operation. Also, the new model strengthens the control over the work of these services, which is in the hands of the Assembly of RNM and its mechanisms.

\section{The Security-intelligence community of R.N.Macedonia}

The Security-Intelligence Community covers the intelligence services in the Republic of North Macedonia: The Intelligence Agency, the Military Service forSecurity and Intelligence, and the Agency for National Security. The holder of intelligence affairs in the country is the Intelligence Agency(IA). It was established by the Law on the Intelligence Agency in 1995 as a separate body of state administration. According to the legal provisions, the Agency is competent to collect data and information relevant to the security and defense of the Republic, as well as the political, economic, and other vital interests of the state, to make early warnings, assessments, and forecasts of tendencies and possibilities of security risks after national security, to collect data and information on the prevention of international terrorism and transnational organized crime, etc. (Law on Intelligence Agency,1995). The head of the Intelligence Agency is a director who is appointed and dismissedby the President of the Republic, to whom he is accountable for his work. The Government may also request accountability to the Director for the work of the Agency. The organizational structure of the Agency consists of departments and separate directorates, namely:Directorate for Hybrid Strategies and Threats Intelligence, Directorate for Terrorism and Other Asymmetric Threats Intelligence, Technical Intelligence Directorate, Security Directorate, and Directorate for General Affairs and Logistics (Intelligence Agency-Organizational structure).

To comply with the laws of other security-intelligence services, at the end of 2019, a new law on the Intelligence Agency was proposed, in order to complete the security system reforms and to make a distinction between the Intelligence Agency and the newly formed Agency for National Security. The new law clearly defines the competence of the Intelligence Agency, which is to collect, process, analyze, exchange, store and protect data and information from abroad that are important for the security, defense, and foreign policy interests of the country(Draft LawontheIntelligence Agency,2019).In January 2021, the Assembly of the R.N. Macedonia adopted the new Law on Intelligence Agency, which defines the Agency as a modern and efficient service forexternal intelligence.

Within the Ministry of Defense and the Army of the RNM is the Military Service for Security and Intelligence(MSSI), which is not a separate organizational unit. According to the Law on Defense, this service performs activities related to the planning, organization, and implementation of intelligence, counterintelligence, and protection of forces in the Ministry of Defense and the Army of 
the R.N. Macedonia. The Law on Defense (in Chapter XI) defines the measures and activities for intelligence and counter-intelligence that are important for the defense of the Republic, and they are: collection, documentation and analysis of intelligence data important for the defense; detection and prevention of intelligence and other subversive activity of foreign military-intelligence and intelligence services, which is performed in the country or abroad, and is aimed at the defense of the Republic; detection and prevention of all forms of terrorist activity aimed at defense; implementation of counterintelligence protection of the tasks and plans, documents, material-technical means, areas, zones, and objects of interest for the defense of the country (Law on Defense,2020). The Military Service for Security and Intelligence is composed of two segments, one part is in the Ministry of Defense, known as the Sector-Service for Military Security and Intelligenceand the second part are the security and intelligence sections in the Army, J-2, S-2, and A-2. The sections in the Army are with double subordination, according to the command line under the General Staff of the ARM and according to the professional line under the head of the Sector-Service for Military Security and Intelligence(Фуиор,et al.2018: 12). TheSector-Service for Military Security and Intelligenceconsists of nine units, while in the section J-2 Intelligence, Counterintelligence and Security (which, in turn, is within the General Staff of the Army), there are special units responsible for intelligence, security, and counterintelligence.

Unlike previous intelligence services, the Agency for National Securi$t y(A N B)$ is more recent. It was established by the Law on Agency forNational Security adopted by the Assembly of the RNM in May 2019. Its establishment is part of a broader process of reforming the security and intelligence services, which is one of the priority reform processes on the road to European integration. In fact, with the launch of the new Agency, the former Directorate forSecurity and Counterintelligence (which was a body within the Ministry of internal affairs) ceased to operate. As an independent body of state administration, the Agency forNational Security is separate from the Ministry of Interior and functions as a separate government agency. Its main goal is the protection of the national security of the state, i.e. protection of independence, sovereignty, constitutional order, fundamental freedoms, and human rights, as well as other matters of interest to national security. According to the Law onthe Agency forNational Security, it is responsible for collecting, processing, analyzing, evaluating, exchanging, storing, and protecting data and information, in order to detect and prevent activities related to security threats and risks to national security such as espionage, terrorism, and its financing, violent extremism, forms of serious and organized criminal activities against the state and other activities aimed at violating the national security of the R.N.Macedonia (Law on Agency for National Security, 2019).

For matters of national security, the Agency shall inform the President of the Republic, the President of the Assembly, the Prime Minister, the Council for Coordination of the Security-Intelligence Community, as well as other 
entities depending on the issue being reported. The Agency is managed by a director who is appointed and dismissed by the Government on the proposal of the Prime Minister, and the director is accountable to the Government of RNM (ibid., 4). The internal organizational set-up of the Agency is based on a functional and territorial principle at the central and regional levels. The organizational structure of the Agency consists of six departments-divisions, four directorates, and regional offices to perform the tasks within the competence of the Agency.

In the security-intelligence community of R.N. Macedonia was added a newly established Operational-Technical Agency (OTA), which has a different role from other agencies. The legislative reform of the communications monitoring system adopted in April 2018 provided the establishment of the OTA as an independent and sovereign state body. In accordance with the Law on Operational-Technical Agency, adopted by the Assembly in 2018, OTA should have an intermediary technical role, providing technical connection between operators and authorized bodies, exclusively on the basis of a court order for interception of communications (Law on The Operational-Technical Agency, 2018). The technical devices for interception of communications and technical documentation available to OTA were taken over by the former Directorate for Security and Counterintelligence - UBK at the Ministry of internal affairs. This means that it is authorized to implement some of the measures and activities that were under the jurisdiction of The Directoratefor Security and Counterintelligence.

According to the legal provisions, the Agency is competent to activate and create technical conditions for interception of communications for the needs of criminal investigations and for protection of the interests of the security and defense of the state. The operational-technical agency does not have access to the content of the intercepted communications and acts as a buffer zone between the bodies authorized to use the interceptions and the operators, exercising in some way expert supervision in the interception system. For example, in 2018 OTA mediated in the activation of the measure for interception of communications in a total of 153 communications for the needs of the authorized bodies in R.N. Macedonia (Report on OTA's Operations, 2018).

The creation of the Agency prevents the concentration of power in one institution (as it was within theDirectoratefor Security and Counterintelligence), which facilitates the expectation. In addition, its establishment prevents the misuse of the measure for interception of electronic communications of citizens by the authorized bodies for interception of communications or operators. In general, in its domain of protection are only the electronic forms of communications between the citizens. The OTA is headed by a director, who is appointed and dismissed by the Assembly of RNM for a term of five years, without the right to re-election, and for his work and the work of OTA, the director is obliged to submit an annual report to the Assembly of RNM (Basic information on OTA). 
For more efficient coordination of the security-intelligence community of Macedonia, a special Law on coordination of the security-intelligence community in 2019 was adopted. According to this Law, the coordination is achieved by implementing the proposals of the Security Council of the RNM related to national security, reviewing the assessments of the security-intelligence services, promoting the cooperation between the security-intelligence services, as well as planned and functional use of their capacities and resources and other matters relating to national security (Law on Coordination of the Security and Intelligence Communityin the RepublicofNorth Macedonia, 2019). Among other things, the coordination enables a joint assessment of the areas of interest to the users, as well as the creation of an integrated security policy.

According to the Law, the Council for Coordination of the Security-Intelligence Community is established. The scope of work of the Council is: to review and implement the proposals of the Security Council of the RNM; to coordinate the work of the security-intelligence services; to consider and assess threats and risks to the national security of the country; to provide guidance, opinions, and conclusions on issues within the competence of the security-intelligence services. The Council has a similar role to the Security Council of the RNM. It consists of the following members: The Prime Minister, the Deputy Prime Minister in charge of implementing the Framework Agreement and the political system, the Ministers of Defense, Interior, Foreign Affairs, the Director of the Intelligence Agency, the Director of the Agency for National Security and the head of the competent organizational unit for military security and intelligence in the Ministry of Defense. Depending on the issues under consideration, the representatives of other state bodies and institutions may also participate in the sessions of the Council. The Council for Coordination of the Security and Intelligence Community is chaired by the Prime Minister, which means that the power of this body is concentrated in the hands of the executive(ibid., 3).

\section{Conclusion}

The Republic of North Macedonia has gone through "Scylla" and "Charybdis" to reach a satisfactory acceptable level of security that guarantees prosperity and affirmation of the country and its security structures. In the past, there have been several unsuccessful attempts by security policy makers to build a modern security-intelligence system in line with the needs of the country and Euro-Atlantic standards. One possible solution was to merge the security and intelligence services into a unified civilian intelligence and counter-intelligence agency to improve the collection and exchange of intelligence. This did not happen, due to the lack of political consensus and support from the institutions that were an important segment for the implementation of the concept of the intelligence community.

Currently, the process of restructuring and shaping the new model of the intelligence community of R.N.Macedonia has been completed and a solid 
legal framework governing the intelligence activity has been established. With the new concept of the security-intelligence community, it is organized in several bodies with precisely defined competencies that will enable efficiency in the operation. At the same time, the new model prevents the concentration of power in one institution and facilitates the expectation and oversight of the intelligence services. 


\section{References:}

Бакрески, О. и Милошевиќ, М. (2010).Современи безбедносни системи: компаративна анализа на земјите од Југоисточна Европа. Скопје: Аутопринт Т.А. и Филозофски факултет.

Бакрески, О. (2018). Безбедносни системи: компаративна анализа. Скопје: Филозофски факултет.

Basic informationson OTA.Available at: https://ota.mk/mk/osnovni-informacii [Accessed 8 October 2020]

Draft Action Plan of the Government of the Republic of Macedonia prepared on the basis of the List of Urgent Reform Priorities for the Republic of Macedonia.(2016).Government of the Republic of Macedonia. Available at:https://www.sep.gov.mk/data/file/PARIRP/Plan of activities for implementation of the urgent reform priorities 2015 (Working document) pdf [Accessed 14 March 2021]

Draft Law onthe Intelligence Agency.(2019). Skopje: Ministry of Justiceof the Republic of North Macedonia.

European Commission Reportson Republic of Macedonia (2015-2020). European Commission. Brussels. Available at: https://www.sep.gov.mk/ category/?id=46 [Accessed 25 February 2021]

Фуиор, Т.еt al. (2018). Насоки за надзор над разузнаването: за парламентарните комисии воСобранието на Република Македонија, ДКАФ.

Law on Agency for National Security.(2019).Official Gazette of RNM No. 108. 28.5.2019. Available at:https://mvr.gov.mk/Upload/Documents/ ZANB\%20108-19(1).pdf [Accessed 11 October 2020]

Law on Coordination of the Security and Intelligence Communityin the Republic of North Macedonia. (2019). Official Gazette of RM No.108/2019.

Law on Defence-unofficial consolidated text.(2020).Skopje:Ministry of Defence of The Republic of North Macedonia.

Law on Electronic Communications.Official Gazette of RM No.39/2014, 188/2014, 44/2015, 193/2015, 11/2018 и 21/2018.Available at : https:/aek. $\mathrm{mk} / \mathrm{wp}$-content/uploads/ 2018 /03/k2 attachments2018ZEK_Prechisten _tekst.pdf [Accessed 26 November 2020]

Law on Intelligence Agency. (1995). Official Gazette of RM No.19/95. 06.04.1995. Available at :https://ia.gov.mk/Documents/ZakonAR.pdf [Accessed 4 January 2021]

Law on Interception of Communications.(2018). Official Gazette of RM No. 71, 2018.

Law on The Operational-Technical Agency. (2018). Official Gazette of RM No.71, 2018.

MacDowall, A. (2015). "Fears for Macedonia's fragile democracy amid 'coup' and wiretap claims".The Guardian. Available at:https://www.theguardian. com/world/2015/feb/27/fears-macedonias-fragile-democracy-amidcoup-wiretap-claims [Accessed 9 March 2021] 
Николов, А. „Анадиза за правната рамка за следењето на комуникациите и нејзината примена“, Фондацијата за интернет и општество - Метаморфозис и Асоцијација за прогресивни комуникации - APC.Available at:https:/metamorphosis.org.mk/ wp-content/uploads/2019/08/Legal-framework-on-interception-ofcommunicationmk.pdf [Accessed 4 March 2021]

Plan 18. (2018). Government of the Republic of Macedonia.Available at: [Accessed 22 March 2021]

Plan 3-6-9. (2017). Government of the Republic of Macedonia. Available at: [Accessed 8 March 2021]

Recommendations of the Senior Experts' Group on systemic Rule of Law issues relating to the communications interception revealed in Spring 2015. (2015). Brussels. Available at:https:/ec.europa.eu/neighbourhood-enlargement/sites/ near/files/news _corner/news/ news-files/20150619_recommendations_ of_the_senior_experts_group.pdf [Accessed 18 March 2021]

Report on OTA's Operations.(2018).Available at: https://ota.mk/adocs/scanizvestaj-ota-2018.pdf [Accessed 23 October 2020]

Спасески, Ј. (2005). Македонија столб на безбедноста и мирот на Балканот. Скопје: Академик и Универзитет „Св.Климент Охридски“- Подициска академија.

Urgent reformprioritiesfor The Former Yugoslav Republicof Macedonia. (2015). European Commission. Available at:https://ec.europa.eu/ neighbourhood-enlargement/sites/near/files/news_corner/news/newsfiles/20150619urgentreform_priorities.pdf [Accessed 18 March 2021]

White paper on Defence . (2012). Ministry of Defence of The Republic of Macedonia.

Чомовски, А. (2007). „Пресуда за “Големото уво“. 15 Јуни. Available at: https:// www.dw.com/mk//пресуда-за-големото-уво/a-2610393[Accessed 3March 2021]

Зенделовски, Г. (2010). „Улогата на Република Македонија во глобалната безбедност и одбрана“, Зборник на трудови-Меѓународна научна конференција,Балканот-безбедносен предизвик за Европа и меѓународната заедница,Охрид: (295-307). 
